\title{
Role of Culex and Anopheles mosquito species as potential vectors of rift valley fever virus in Sudan outbreak, 2007
}

\author{
AlaaEddeen M Seufi, Fatma H Galal
}

\begin{abstract}
Background: Rift Valley fever (RVF) is an acute febrile arthropod-borne viral disease of man and animals caused by a member of the Phlebovirus genus, one of the five genera in the family Bunyaviridae. RVF virus (RVFV) is transmitted between animals and human by mosquitoes, particularly those belonging to the Culex, Anopheles and Aedes genera.

Methods: Experiments were designed during RVF outbreak, 2007 in Sudan to provide an answer about many raised questions about the estimated role of vector in RVFV epidemiology. During this study, adult and immature mosquito species were collected from Khartoum and White Nile states, identified and species abundance was calculated. All samples were frozen individually for further virus detection. Total RNA was extracted from individual insects and RVF virus was detected from Culex, Anopheles and Aedes species using RT-PCR. In addition, data were collected about human cases up to November $24^{\text {th }}, 2007$ to asses the situation of the disease in affected states. Furthermore, a historical background of the RVF outbreaks was discussed in relation to global climatic anomalies and incriminated vector species.

Results: A total of 978 mosquitoes, belonging to 3 genera and 7 species, were collected during Sudan outbreak, 2007. Anopheles gambiae arabiensis was the most frequent species (80.7\%) in White Nile state. Meanwhile, $C X$. pipiens complex was the most abundant species (91.2\%) in Khartoum state. RT-PCR was used and successfully amplified $551 \mathrm{bp}$ within the M segment of the tripartite negative-sense single stranded RNA genome of RVFV. The virus was detected in female, male and larval stages of Culex and Anopheles species. The most affected human age interval was 15-29 years old followed by $\geq 45$ years old, 30-44 years old, and then 5-14 years old. Regarding to the profession, housewives followed by farmers, students, shepherd, workers and the free were more vulnerable to the infection. Furthermore, connection between human and entomological studies results in important human casevulnerability relatedness findings.
\end{abstract}

Conclusion: Model performance, integrated with epidemiologic and environmental surveillance systems should be assessed systematically for RVF and other mosquito-borne diseases using historical epidemiologic and satellite monitoring data. Case management related interventions; health education and vector control efforts are extremely effective in preparedness for viral hemorrhagic fever and other seasonal outbreaks.

\footnotetext{
* Correspondence: alaaseufi@yahoo.com

Department of Entomology, Faculty of Science, Cairo University, Giza, Egypt,

12211
}

\section{() Biomed Central}

(c) 2010 Seufi and Galal; licensee BioMed Central Ltd. This is an Open Access article distributed under the terms of the Creative Commons Attribution License (http://creativecommons.org/licenses/by/2.0), which permits unrestricted use, distribution, and reproduction in any medium, provided the original work is properly cited. 


\section{Background}

Rift Valley fever (RVF) is an acute febrile arthropodborne viral disease of man and animals caused by a member of the Phlebovirus genus, one of the five genera in the family Bunyaviridae. RVF virus (RVFV) is transmitted between animals and human by mosquitoes, particularly those belonging to the Culex, Anopheles and Aedes genera [1,2]. Transmission is mostly horizontal, but a vertical mode was described for some Aedes species $[3,4]$. RVFV is carried in the eggs of Aedes mosquitoes which breed in isolated depressions called dambos found in the vast grassland areas. At flooding of the dambos during periods of extensive and widespread rainfall, the eggs of the Aedes mosquitoes hatch and the subsequent adults transmit the virus to domestic animals including sheep, goats, cattle, camels, and buffalos [5]. These depressions also serve as good habitats for Culex and Anopheles mosquito species. When Aedes mosquitoes infect domestic animals with RVFV, virus amplification occurs in these vertebrate hosts, leading to propagation into various Culex and Anopheles species that are capable of transmitting the virus to a wider area beyond the area of the original outbreaks by wind-borne dispersal [6]. Although RVFV is, in most cases, transmitted to humans by mosquitoes, it may also be transmitted through direct contact with secretions of infected animals and meat. The professional nature of some groups, such as doctors and veterinarians working in slaughterhouses, made them more vulnerable than others to infection (because the virus is not vital outside the body). Good cooking of meat may help to eliminate the virus from it [7].
The disease in animals is characterized by high rates of abortion and death of young ruminants [1]. Human disease symptoms are often limited to a flu-like syndrome with transient fever, rigor (shivering), headache, severe muscle and joint pains, photophobia and anorexia, sometimes with a petaechial rash, nausea, vomiting and epistaxis. The symptomatic course is 4 to 7 days leading to full recovery in 2 weeks. However in severe cases, case fatality rates are about $1 \%$ and usually associated with hemorrhagic manifestations of the disease. Meningoencephalitis also occurs in about $1 \%$ of infections, but does not usually result in death. Ocular sequellae occur in a moderate percentage of cases and may result in impaired vision or even blindness, which might be permanent [2]. Human cases are mainly caused by direct contact with infected animal body fluids after abortion or slaughtering viremic animals and by mosquito bites. When an epizootic occurs in animals, it is easily transmitted to humans leading to an epidemic [8].

RVFV was first identified in 1931 during an investigation into an epizootic among sheep on a farm in the Rift Valley of Kenya. Since then, outbreaks have been reported in sub-Saharan and North Africa. Data presented in Table 1 described all previously reported RVFV outbreaks after 1931. In 1950-51, a major epizootic in Kenya caused 500,000 abortion and 100,000 deaths in sheep. In 1977, an epidemic of RVF was recoded in Egypt. Cx. pipiens was incriminated in disease transmission and dissemination $[9,10]$. A major outbreak occurred in Senegal in 1987 and 2003. Both $C x$. poicilipes and Ae. vexans were collected from the affected sites [11]. In 1997-98, Faye et al. reported a major outbreak occurred in Eastern Africa (Cx. theileri),

Table 1 Historical background on the recorded outbreaks in Africa and Asia continents showing the year of outbreak, country and incriminated arthropod species.

\begin{tabular}{|c|c|c|c|}
\hline Year of outbreak & Affected country & Collected arthropods & Reference \\
\hline 1997-98 and December 2006 & Kenya & $\begin{array}{l}\text { Culex zombaensis, Anopheles coustani, Aedes mcintoshi*, } \\
\text { Mansonia africana, and M. uniformis }\end{array}$ & [8] \\
\hline 1997-98 and from January to May 2007 & Tanzania & Aedes mcintoshi* & {$[12]$} \\
\hline 1997-1998 & Eastern Africa, & Culex theileri* $^{*}$ & [11] \\
\hline 1977 & Egypt & Culex pipiens* & {$[9,10]$} \\
\hline 1987, 2003 & Senegal & Culex poicilipes* and Aedes vexans & [11] \\
\hline 23 Oct 2000 & Kingdom Saudi Arabia & $\begin{array}{c}\text { Culex pipiens complex, Aedes vexans arabiensis, Ae. Vittatus, } \\
\text { Ae. (Stegomyia) nilineatus, Aedes vexans arabiensis and Culex (culex) } \\
\text { triteniorynchus* }\end{array}$ & {$[13,14,16]$} \\
\hline 19 Oct 2000 & Yemen & Not defined & {$[15]$} \\
\hline $\begin{array}{l}\text { 1987, } 1998 \text { and October } \\
2003\end{array}$ & Mauritania & $\begin{array}{l}\text { An. pharoensis, rhodesiensis, rufipes, C. antennatus, decens, neavei, } \\
\text { perfuscus, poicilipes, quinquefasciatus*, Sandflies, Biting midges. } \\
\text { Culex poicilipes*, antennatus, Mansonia uniformis (2003) }\end{array}$ & {$[11,34,35]$} \\
\hline Oct, 2007 to Jan, 2008 & Sudan. & Culex pipiens complex, Anopheles gambae arabiensis*, Ae. aegypti. & {$[8,36]$} \\
\hline 1997-98 and Dec 2006 to Feb 2007 & Somalia & Not defined & [12] \\
\hline
\end{tabular}

*Most abundant species in the collection. 
Kenya (Cx. zombaensis, An. coustani, Ae. mcintoshi, M. africana, and M. uniformis), Somalia, Mauritania (An. pharoensis, An. rhodesiensis, An. rufipes, Cx. antennatus, $C x$. decens, Cx. neavei, Cx. perfuscus, Cx. poicilipes, $C x$. quinquefasciatus, Sandflies, Biting midges) and Tanzania (Ae. mcintoshi) [11]. Mauritania registered another outbreak in 2003. Cx. poicilipes, Cx. antennatus, and $M$. uniformis were incriminated in disease transmission [11]. Additional major outbreak was recorded in Kenya, Tanzania, Sudan and Somalia [8,12]. In September 2000, RVF cases were confirmed in Saudi Arabia (Cx. pipiens complex, Ae. vexans arabiensis, Ae. Vittatus, Ae. (Stegomyia) nilineatus and $C x$. (cx.) triteniorynchus) and Yemen, marking the first reported occurrence of the disease outside the African continent and raising concerns that it could extend to other parts of Asia and Europe [13-15]. During these multiple outbreaks and epidemics, the virus exhibited an amazing flexibility to adapt to different ecological contexts and to take advantage of climatic change and environmental disruptions (dam building, land irrigation, etc.). Such an adaptive ability resulted in a high toll of deaths, ailments and economic losses during its recent emergence episodes [16].

Since livestock immunization against RVF has so far appeared difficult to implement efficiently in areas of endemicity, strengthened surveillance, early detection, management of cases seemed to be among the best options to prevent extension of RVF epidemic foci. Precise estimation of specific weight for each risk factor is a considerable guide to construct an effective outbreak control plan. Insufficient entomological studies and surveys were conducted and resulted in a vague evaluation of the vector role in RVFV transmission and dissemination in Sudan. For that reasons, this study was conducted to answer some raised questions about the role of vector(s) in RVFV outbreak, 2007 in Sudan.

\section{Methods}

\section{Insect collection and identification}

Adult and immature stages of mosquitoes were collected on December 2007 from their breeding sites in White Nile (affected) and Khartoum (not affected) states. Adults were collected using $\mathrm{CO}_{2}$-baited light traps and aspirators while immature stages were collected by sieving potential larval habitats with dippers. 476 and 502 mosquitoes were collected from White Nile and Khartoum states, respectively. All specimens were identified at Sudan's National Health Laboratory. Mosquitoes were pooled concerning their site of collection, species, sex and stage (larva, pupa or adult). Mosquitoes were then frozen for further virus detection. In both collection sites, livestock (sheep, goats, cattle, camels and cows) were housed at night in very close contact to their owners.

\section{Molecular detection of RVFV in mosquitoes RNA extraction}

Total RNA was extracted from individual insects using RNeasy kit according to manufacturer's instructions (QIAGEN). The RNA was dissolved in DEPC-treated water, quantified spectrophotometrically and analyzed on $1.2 \%$ agarose gel.

\section{Reverse transcription of RNA}

For synthesis of first strand cDNA, reverse transcription reactions were performed using oligo dT primer (5'TTTTTTTTTTTTTTT-3'). Each $25 \mu$ reaction mixture containing $2.5 \mu \mathrm{l}$ of $5 \times$ buffer with $\mathrm{MgCl}_{2}, 2.5 \mu \mathrm{l}$ of 2.5 mM dNTPs, $1 \mu \mathrm{g}$ of primer, $2 \mu \mathrm{g}$ RNA, $200 \mathrm{U}$ reverse transcriptase enzyme. RT-PCR amplification was performed in a thermal cycler (Eppendorf) programmed at $42^{\circ} \mathrm{C}$ for $1 \mathrm{hr}, 72^{\circ} \mathrm{C}$ for $10 \mathrm{~min}$. cDNA was then stored at $-20^{\circ} \mathrm{C}$ until used.

\section{PCR amplification using RVFV specific primer set}

Total PCR reaction volume of $25 \mu \mathrm{l}$ containing $10 \mathrm{mM}$ Tris $\mathrm{HCl}$ (pH 8.3), $25 \mathrm{mM} \mathrm{KCI}, 4 \mathrm{mM} \mathrm{MgCl} 2,200 \mu \mathrm{M}$ dNTPs, 1 U Taq DNA polymerase (AmpliTaq, PerkinElmer), $2 \mu \mathrm{l}$ of the $10 \mathrm{pmol}$ primer and $1 \mu \mathrm{l}$ of the product of reverse transcriptase reaction was employed. PCR primers for this assay (Fwd: 5'-GAC TAC CAG TCA GCT CAT TAC C-3' and Rev: 5'-TG TGA ACA ATA GGC ATT GG-3') were designed to anneal to $G_{2}$ glycoprotein region within the $M$ segment of the tripartite negativesense single stranded RNA genome of RVFV. PCR reaction was cycled first in a 9700 thermal cycler (PerkinElmer) programmed at $94^{\circ} \mathrm{C}$ for $5 \mathrm{~min}$ (one cycle), then followed by 40 cycles at $94^{\circ} \mathrm{C}$ for $15 \mathrm{~s}, 50^{\circ} \mathrm{C}$ for $15 \mathrm{~s}$, and $72^{\circ} \mathrm{C}$ for $30 \mathrm{~s}$. Reaction was then incubated at $72^{\circ} \mathrm{C}$ for 10 min for final extension [17]. Two $\mu \mathrm{l}$ of loading dye were added prior to loading of $10 \mu \mathrm{l}$ per gel pocket. Electrophoresis was performed at 80 Volt with $0.5 \times$ TBE buffer in $1.5 \%$ agarose gel. Gel was stained in $0.5 \mu \mathrm{g} / \mathrm{ml}(\mathrm{w} / \mathrm{v})$ ethidium bromide solution. Finally, gel was visualized and photographed by using gel documentation system.

\section{Human studies \\ Case definitions}

A suspected human RVFV case-patient was defined as a person with fever associated or not with hemorrhagic jaundice, neurological symptoms or any person who died with overt hemorrhagic fever symptoms from October through December 2007. A confirmed human RVFV case-patient was defined by more than one of these laboratory tests: immunoglobulin M (IgM), RTPCR or virus isolation positive results.

\section{Human investigations}

In affected areas, the investigation was conducted under the supervision of the chief of the sanitary district. For each case, blood samples were collected and an interview in which information was gathered about sex, age, 
date of fever onset, profession and hemorrhagic symptoms for all case-patients and their contacts. All data of human studies were kindly supported by the Sudan's National Health Laboratory, Department of Epidemiology at the Federal Ministry of Health, Sudan government.

\section{Historical background on RVFV outbreaks}

Outbreaks of RVFV were followed up through publications and reports. Table 1 presented a complete history of the reported epizootics of RVFV, including the year of outbreak, affected countries, collected arthropods that were incriminated in disease transmission and dissemination and the reference reporting the epizootics.

\section{Results}

\section{Entomological results}

A total of 978 mosquitoes, belonging to 3 genera and 7 species, were collected (Tables 2 and 3). Among the species collected from White Nile state, Anopheles gambiae arabiensis was the most frequent species (80.7\%), followed by Culex pipiens complex (8.8\%), Aedes aegypti (5.0\%), An. coustani (2.9\%), Cx. poicilipes (1.7\%), then both Ae. mcintoshi and Ae. vexans (0.4\%). Meanwhile, $C x$. pipiens complex was the most abundant species (91.2\%) collected from Khartoum state, followed by $C x$. poicilipes (4.4\%), An. gambiae arabiensis (3.2\%), An. coustani (0.8\%) and Ae. mcintoshi (0.4\%). Neither Aedes aegypti nor Ae. vexans was collected from Khartoum. Overall, $C x$. pipiens complex was more abundant than An. gambiae arabiensis. Immature and adult species collected from the two sites are presented in Tables 2 and 3. A total of 26 monospecific pools were constituted regarding to species, stage and site of collection. Individual mosquitoes were then submitted to RT-PCR assay for RVFV detection.

\section{RT-PCR amplification using RVFV specific primer set}

Two oligonucleotide primers were designed to amplify $551 \mathrm{bp}$ within the $\mathrm{M}$ segment of the tripartite negativesense single stranded RNA genome of RVFV [17], and

Table 2 A key table indicates the collected species number, stage, abundance and positive RT-PCR samples from White Nile state.

\begin{tabular}{|c|c|c|c|c|c|c|c|}
\hline \multirow[t]{2}{*}{ Species } & \multirow[t]{2}{*}{ Total no. of collected species } & \multicolumn{4}{|c|}{ Stage } & \multirow[t]{2}{*}{ Species abundance* } & \multirow[t]{2}{*}{ No. of positive PCR samples } \\
\hline & & Larva & Pupa & Male & Female & & \\
\hline An. gambiae arabiensis & 384 & 28 & 4 & 30 & 322 & $80.7 \%$ & $3 \mathrm{~L}+2 \mathrm{M}+26 \mathrm{~F}^{* *}=31$ \\
\hline An. coustani & 14 & 2 & - & 2 & 10 & $2.9 \%$ & $1 \mathrm{~L}+2 \mathrm{~F}=3$ \\
\hline Cx. pipiens complex & 42 & 22 & 4 & - & 16 & $8.8 \%$ & $4 \mathrm{~L}+1 \mathrm{~F}^{* * *}=5$ \\
\hline Cx. poicilipes & 8 & 6 & - & - & 2 & $1.7 \%$ & $1 F=1$ \\
\hline Ae. aegypti & 24 & 22 & - & - & 2 & $5.0 \%$ & $8 \mathrm{~L}+2 \mathrm{~F}^{* * * *}=10$ \\
\hline Ae. mcintoshi & 2 & - & - & - & 2 & $0.4 \%$ & 0 \\
\hline Ae. vexans & 2 & 2 & - & - & - & $0.4 \%$ & 0 \\
\hline Total & 476 & 82 & 8 & 32 & 354 & $100 \%$ & 50 \\
\hline
\end{tabular}

* Abundance $=$ number of individuals of one species/total number of mosquitoes collected (approximated to one decimal).

** 24 gravid +2 ungravid females.

*** Gravid females.

**** Ungravid female.

Table 3 A key table indicates the collected species number, stage, abundance and positive RT-PCR samples from Khartoum state.

\begin{tabular}{|c|c|c|c|c|c|c|c|}
\hline \multirow[t]{2}{*}{ Species } & \multirow[t]{2}{*}{ Total no. of collected species } & \multicolumn{4}{|c|}{ Stage } & \multirow[t]{2}{*}{ Species abundance* } & \multirow[t]{2}{*}{ No. of positive PCR samples } \\
\hline & & Larva & Pupa & Male & Female & & \\
\hline An. gambiae arabiensis & 16 & 16 & - & - & - & $3.2 \%$ & $2 \mathrm{~L}=2$ \\
\hline An. coustani & 4 & 2 & - & - & 2 & $0.8 \%$ & - \\
\hline Cx. pipiens complex & 458 & 446 & - & 4 & 8 & $91.2 \%$ & $22 \mathrm{~L}+2 \mathrm{~F}^{* *}=24$ \\
\hline Cx. poicilipes & 22 & 16 & 2 & - & 4 & $4.4 \%$ & - \\
\hline Ae. aegypti & - & - & - & - & - & 0.0 & - \\
\hline Ae. mcintoshi & 2 & 2 & - & - & - & $0.4 \%$ & - \\
\hline Ae. vexans & - & - & - & - & - & 0.0 & \\
\hline Total & 502 & 482 & 2 & 4 & 14 & $100 \%$ & 26 \\
\hline
\end{tabular}

* Abundance $=$ number of individuals of one species/total number of mosquitoes collected (approximated to one decimal).

** Ungravid female. 


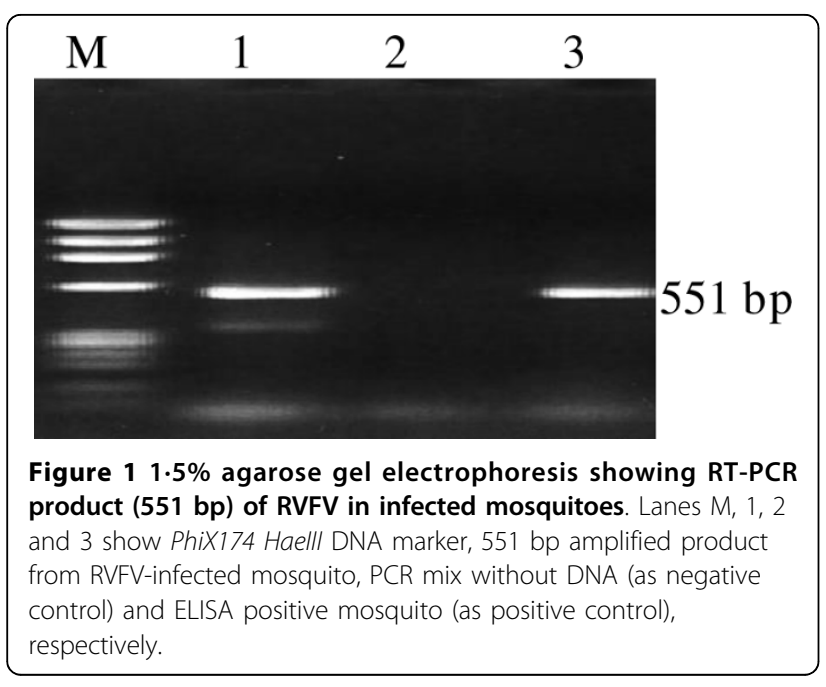

were successfully used in RT-PCR. Electrophoretic analysis of the RT-PCR product on agarose gels revealed that the primers amplified a single band of expected size of 551 bp only in the RNA extracted from RVF-infected samples. PCR mix with no template was used as negative control (Fig. 1). RVFV was successfully detected in larvae and females of An. gambiae arabiensis, An. coustani, Cx. pipiens complex and Ae. aegypti collected from White Nile state (Table 2). Infection rate was estimated as $(31 / 476) 6.5,(3 / 476) 0.6,(5 / 476) 1.1$ and $(10 / 476)$ $2.1 \%$, respectively. No virus was detected in either $A e$. mcintoshi or Ae vexans, while only one female of $C x$. poicilipes was tested positive for RVFV collected from White Nile state (Table 2). In parallel, RVFV was successfully detected in both larvae and females of $C x$. pipiens complex and Cx. poicilipes collected from Khartoum state (Table 3). Infection rate was estimated as (20/502) 4 and (4/502) $0.8 \%$, respectively. No virus was detected in Ae. mcintoshi collected from Khartoum state. Two larvae, one of An. gambiae arabiensis and one of An. coustani were tested positive for RVFV collected from Khartoum state (Table 3). It is noteworthy to mention that only two male samples of An. gambiae arabiensis were tested positive for RVFV collected from White Nile state (Table 2).

\section{Human results}

The different cases recorded in the affected states (White Nile, Gazira and Sinnar) from the first onset up to Nov $24^{\text {th }}, 2007$ are presented in Table 4. Gazira state hospitals received the highest number of suspected cases (287/451), followed by White Nile (111/451) and Sinnar $(53 / 451)$ states. The cumulative number of deaths was arranged in the same order. The first cases appeared in southern areas of Algabalain locality in White Nile state at October $4^{\text {th }}, 2007$. According to the doctors and
Table 4 Epidemiological situation of human cases recorded in the affected states up to Nov $24^{\text {th }}, 2007$.

\begin{tabular}{|c|c|c|c|c|c|c|}
\hline \multirow[t]{3}{*}{ State } & \multicolumn{3}{|c|}{ Cumulative } & \multicolumn{3}{|c|}{ Laboratory results } \\
\hline & \multirow[t]{2}{*}{ Cases } & \multirow[t]{2}{*}{ Deaths } & \multirow[t]{2}{*}{ CFR\%* } & \multirow[t]{2}{*}{ Total samples } & \multicolumn{2}{|c|}{ Positive cases } \\
\hline & & & & & ELISA & PCR \\
\hline White Nile & 111 & 65 & 58.6 & $27+2$ & $11 / 27$ & $0 / 2$ \\
\hline Gazira & 287 & 113 & 39.4 & $34+3$ & $15 / 34$ & $1 / 3$ \\
\hline Sinnar & 53 & 15 & 28.3 & 13 & $4 / 13$ & - \\
\hline Total & 451 & 193 & 42.8 & $74+5$ & $30 / 74$ & $1 / 5$ \\
\hline
\end{tabular}

*CFR: Case Fatality Rate (approximated to one decimal).

Cumulative cases, deaths, case fatality rate in relation to laboratory results are shown.

citizens in that area, the first symptoms were hemorrhage and fever with rapid death. All reported cases in the beginning of the outbreak were scattered and did not reach any health facilities. After that the cases started to be reported from Sinnar then Gazira states. It was observed that the number of infections and subsequent deaths were more frequent in males than females (Table 5). The most affected age interval was 15-29 years old followed by $\geq 45$ years old, 30-44 years old, and then 5-14 years old. Regarding to the profession, housewives followed by farmers, students, shepherd, workers and the free were more vulnerable to infection than others (Table 5). Majority of cases appeared with hemorrhagic symptoms. $2-5 \%$ of all cases exhibited eye complications and $1 \%$ exhibited meningococcal meningitis. From the 451 reported case patients, 74 blood samples were submitted to ELISA and 5 samples to real time PCR investigation. Only 30 samples of ELISA and one sample of PCR were tested positive (Table 4). The overall case-fatality rate (CFR) was estimated as $42.8 \%$ in regard to the 451 reported cases (Table 4). Regarding to the fact that the case-fatality rate for infections with RVFV in humans is about $1 \%$, the expected population infected with RVFV is 19303 cases.

\section{Discussion and Conclusions}

This work was developed by an expert Egyptian team on request of the Sudanese Federal Ministry of Health and the author (A.S.) was one of this team.

The low diversity of the mosquito species collected in this survey may be due to natural abundance of mosquito species (high abundance of Culex and Anopheles

Table 5 Relationship between RVFV infection and some observed parameters among 451 cases.

\begin{tabular}{|c|c|c|c|c|c|}
\hline Parameter & $<5$ years & $5-14 y$ & $15-29 y$ & $30-44 y$ & $>45$ years \\
\hline Age & 2 & 32 & 159 & 120 & 138 \\
\hline Gender & & $290 \%$ & & & 161 우 \\
\hline Profession* & $128 \mathrm{HW}$ & $100 \mathrm{~F}$ & $66 \mathrm{~S}$ & $38 \mathrm{Sh}$ & 21 Free 73 Others \\
\hline
\end{tabular}

*HW: housewives, F: Farmer, S: Student and Sh: Shepherd. 
species). Alternatively, it might be because the mosquito captures were undertaken at the end of the rainy season, when most breeding sites had dried up and/or due to the intensive use of pesticides to control blood sucking insect vectors during outbreak. This hypothesis was further strengthened by the small number of mosquitoes caught (978) and the low number of Aedes mosquitoes, a vector species of RVFV in West Africa [18]. Among all adult and immature mosquito stages collected, $C x$. pipiens complex (51.1\%) and An. gambiae arabiensis (40.9\%) were the most represented species. Most of the collected mosquito species, especially Culex species [19], were previously incriminated in RVFV transmission and dissemination (Tables 1, 2 and 3). In addition, feeding preference studies showed that $C x$. pipiens fed preferentially on pigeons but also on human at indoors. However, Anopheles species fed preferentially on human but also on other mammals. These considerations on Culex and Anopheles biology and ecology as well as its experimentally demonstrated vectorial competence to RVFV (Table 1) constituted clues pointing to their relative role in RVFV transmission cycles. Excluding gravid females (to avoid false positive results), the relative role of $A n$. gambiae arabiensis in transmission of RVFV in White Nile and Khartoum states was $1.5 \%$ and $0.4 \%$, respectively. Meanwhile, the relative role of $C x$. pipiens complex in transmission of RVFV was $0.8 \%$ and $4.8 \%$ in White Nile and Khartoum states, respectively. In case of White Nile state, the relative roles of An. coustani, $C x$. poicilipes and Ae. aegypti were 0.6, 0.2 and $2.1 \%$, respectively. High relative role in case of Ae aegypti may be attributed to the high number of positive detections in relation to the number of collected samples. Although the choice of a 1-month period, for monitoring mosquito natural abundance is quite a short time, it was assumed to be a critical period for RVFV outbreak. In addition, we were quite a bit late in the transmission season and tried to follow up the outbreak as soon as we could launch it.

RT-PCR assay is considered as specific, sensitive tool for RVF diagnosis in the early phase of the disease and its results do not differ significantly from those obtained by virus isolation [20]. Successful RT-PCR detection of RVFV in female mosquito species was considered as a precursor for viral circulation in these species (incriminated in dissemination or acquired the virus in its midgut only). Meanwhile, successful RT-PCR detection of RVFV in male and larval stages, although at very low rates, referred to transovarial (vertical) transmission of the virus within these mosquito species. It may also refer to possible venereal RVFV transmission when a male being infected vertically and then infecting the female during mating. RVFV was known to be carried in the eggs of Aedes mosquitoes which can survive for several years in the dried mud [21]. These mosquitoes breed in isolated depressions called dambos found in the vast grassland areas. On flooding, Culex mosquito species (bread in dambos) play important role in virus circulation $[22,23]$. The survival of RVFV during interepizootics was believed to depend on transovarial transmission of the virus in floodwater Aedes mosquitoes [4].

Satellite monitoring (June-September, 2007) showed that most of the central Sudan could be unusually subjected to heavy rainfall, and generated RVF risk warnings for central and southern Sudan in July-September. In late October, RVF outbreaks were reported by World Health Organization (WHO) in humans in Sudan in White Nile, Sinnar, and Gazira states. By early November 2007, 329 human cases, including 96 deaths were reported. The cases being reported in Gazira State are in an area close to irrigation canals and are linked to naturally occurring cycles involving livestock and mosquitoes which are abundant in the irrigation zone. In parallel, many previously studied outbreaks were reported to occur during heavy rainfall seasons in various sub-Saharan countries including Kenya, Somalia, Tanzania, Senegal, Eastern Africa, Mauritania, Egypt and more recently in Saudi Arabia and Yemen. Earlier works suggested that epizootics and epidemics of RVFV occur periodically after heavy rains that flood natural depressions in the grasslands of sub-Saharan Africa [24,25]. In addition to three outbreaks recorded in neighboring countries (Table 1), Sudan was subjected to the heaviest rainfall season reported in the last forty years. Given the wide geographic and ecological range of RVFV, it is necessary to monitor large areas for conditions that may trigger the emergence of mosquito vectors that could spread RVF. Furthermore, there has been increased scientific interest in the connection between global climatic anomalies and disease outbreaks [26]. RVFV is one example of a disease whose outbreaks have been shown to be closely coupled with climate anomalies [25].

Overall connection between human and entomological results with regard to recorded outbreaks in neighboring countries were definite warnings for the incoming RFV outbreak in Sudan, especially that conditions of emerging epidemics were almost certain. Furthermore, the potential of RVF as a disease emerging in new areas was first documented in Egypt in 1977 [2], and since then, epidemics have occurred in Mauritania (1987 to 1988 and 1998), Madagascar (1990 to 1991), Egypt (1993), and eastern Africa (in Kenya, Somalia, and Tanzania) $[27,28]$. Recently, the outbreak on the Arabian Peninsula (in Yemen and Saudi Arabia) represented the first case of RVF outside Africa [29,30].

Although virus isolation (VI) is considered as gold standard method, IgM-ELISA method avoids false 
positive results due to the presence of rheumatoid factor and antinuclear antibodies. On the other hand, anti-RVF IgM antibodies were estimated to persist at a detectable level for up to 6 months in chronic infections [31]. However, combination of ELISA and RT-PCR assays is very important for rapid and efficient identification of RVFV during outbreaks. The present data and those obtained during the epidemics of RVF in Mauritania [11], in Kenya [32], as well as in Saudi Arabia and Yemen [33] demonstrated the importance of combining diagnostic assays for accurate and comprehensive detection of RVFV infection. The present results indicated that males of 15-29 years old were more susceptible than females. In parallel, housewives and farmers were the most susceptible people to RVFV infection (Table 5). These results may be related to their more vulnerability to the vector as well as to socioeconomic/professional activities which allow a direct contact with infected animals. Agreeable results were presented by Woods et al. [32] who stated that children $<15$ years of age were significantly less likely to have had recent RVFV infection. A relation between virus infection and direct contact with animals was reported by Faye et al. [11]. Indeed, those at highest risk include butchers and others who come in contact with animals (e.g., slaughterhouse workers, tanners, and herdsmen), who represent a large part of the population living in these areas. Although WHO estimated that the human mortality rate due to $\mathrm{RVFV}$ is $\approx 1 \%-2 \%$ of infected patients, the number of recorded deaths during this outbreak was 193 among 451 infected patients when the laboratory data were considered exclusively. This means that the number of infected but not officially recorded is about 19303 cases.

Conclusively, the present work reported that Culex and Anopheles were collected in relatively high numbers during Sudan outbreak, 2007. Because the mere presence of a mosquito species during the outbreak does not mean that it is involved in transmission cycle of RVFV, RT-PCR was used and successfully detected RVFV in female, male and larval stages of Culex and Anopheles species. Furthermore, connection between human and entomological studies results in important human case-vulnerability relatedness findings. It is noteworthy that validated RVF forecast models may provide early warning ( $\sim 3$ months) for RVF epidemics in Africa. Model performance, integrated with epidemiologic and environmental surveillance systems, should be assessed systematically for RVF and other mosquito-borne diseases using historical epidemiologic and satellite monitoring data. Case management related interventions; health education and vector control efforts are extremely effective in preparedness for viral haemorrhagic fever and other seasonal outbreaks. Further confirmatory transmission studies are very important to determine the vectorial capacity of the incriminated species in this study.

\section{Acknowledgements}

We want to thank Prof Thomas A. Miller for his endless support and advice, and Prof Bradley A. Mullens for his valuable comments that help to improve the style of this paper. Thanks go to the Department of Epidemiology at the Federal Ministry of Health, Sudan government for supporting human results in this study. Also, thanks should be extended to the Faculty of Science, Cairo University for providing kits and chemical supply to complete this work.

\section{Authors' contributions}

AMS: Designed the overall study, carried out the molecular genetic studies optimization, performed data analysis, interpretation and manipulation, drafted and revised the manuscript, conceived of the study and participated in its coordination. FHG: Participated in the design of the study, participated in the optimization of molecular genetic studies, performed data analysis and interpretation, participated in editing of the manuscript, conceived of the study and participated in its coordination. All authors have read and approved the final manuscript.

\section{Competing interests}

The authors declare that they have no competing interests.

Received: 26 August 2009

Accepted: 11 March 2010 Published: 11 March 2010

\section{References}

1. Easterday B, McGavran M, Rooney J, Murphy L: The pathogenesis of Rift Valley fever in lambs. Am J Vet Res 1962, 23:470-479.

2. Laughlin L, Meegan J, Strausbaugh L, Morens D, Watten R: Epidemic Rift Valley fever in Egypt: observations of the spectrum of human illness. Trans R Soc Trop Med Hyg 1979, 73:630-633.

3. Chevalier V, Lancelot R, Thiongane Y, Sall B, Diaité A, Mondet B: Rift Valley Fever in Small Ruminants, Senegal, 2003. Emerg Infect Dis 2005, 11:1693-1700.

4. Linthicum K, Davies F, Kairo A, Bailey C: Rift Valley fever virus (family Bunyaviridae, genus Phlebovirus). Isolations from Diptera collected during an inter-epizootic period in Kenya. J Hyg (London) 1985, 95:197-205.

5. Mondet B, Diaïté A, Ndione J, Fall A, Chevalier V, Lancelot R, Ndiaye M, Ponçon N: Rainfall patterns and population dynamics of Aedes (Aedimorphus) vexans arabiensis, Patton 1905 (Diptera: Culicidae), a potential vector of Rift Valley Fever virus in Senegal. J Vector Ecol 2005, 30:102-106.

6. Mclntosh B: Rift Valley fever. 1. Vector studies in the field. J South Africa Veterinary Assoc 1972, 43:391-395.

7. Acha P, Szyfres B: Zoonoses and Communicable Diseases Common to Man and Animals. Washington, D. C.: Pan American Health Organization/ World Health Organization Scientific Publication No. 503, 21987.

8. Abdel Aziz M: Rift valley fever: the story unfolds sudanese. J Public Health 2008, 3:5-10

9. El-Akkad A: Rift Valley fever outbreak in Egypt. October-December 1977. J Egypt Public Health Assoc 1978, 53:123-128.

10. Meegan J, Hoogstraal H, Moussa M: An epizootic of Rift Valley fever in Egypt in 1977. Vet Rec 1979, 105:124-125.

11. Faye O, Diallo M, Diop D, Bezeid O, Bâ H, Niang M, Dia I, Mohamed S, Ndiaye K, et al: Rift Valley Fever Outbreak with East-Central African Virus Lineage in Mauritania, 2003. Emerg Infect Dis 2007, 13:7.

12. Centers for Disease Control and Prevention, Wkly Epidemiol Rec: Outbreaks of Rift Valley fever in Kenya, Somalia and United Republic of Tanzania, December 2006-April 2007. 2007, 82:169-178.

13. Jupp P, Kemp A, Grobbelaar A, Lema P: The 2000 epidemic of Rift Valley fever in Saudi Arabia: mosquito vector studies. Med Vet Entomol 2002, 16:245-252.

14. Miller B, Godsey M, Crabtee M, Savage H, Al-Mazrao Y, Al-Jeffri M: Isolation and genetic characterization of Rift Valley fever virus from Aedes vexans arabiensis, Kingdom of Saudi Arabia. Emerg Infect Dis 2002, 8:1492-4. 
15. Centers for Disease Control and Prevention, Wkly Epidemiol Rec: Outbreak of Rift Valley fever, Yemen, August-October 2000. 2000, 48:392-395.

16. Centers for Disease Control and Prevention, August-November Report Update: Outbreak of Rift Valley fever-Saudi Arabia. Morb Mortal Wkly Rep 2000, 49:982-985.

17. Ibrahim $M$, Turell M, Knauert F, Lofts R: Detection of Rift Valley fever virus in mosquitoes by RT-PCR. Molecular and Cellular Probes 1997, 11:49-53.

18. Zeller H, Fontenille D, Traore-Lamizana M, Thiongane Y, Digoutte J: Enzootic activity of Rift Valley fever virus in Senegal. Am J Trop Med Hyg 1997, 56:265-272.

19. Turell M, Gargan T, Bailey C: Replication and Dissemination of Rift Valley Fever Virus in Culex pipiens. Am J Trop Med Hyg 1984, 33:176-181.

20. Sall A, Macondo E, Sene O, Diagne M, Sylla R, Mondo M, Girault L, Marrama L, Spiegel A, other authors: Use of reverse transcriptase PCR in early diagnosis of Rift Valley fever. Clinic Diagnos Lab Immunol 2002, 9:713-715

21. O'Malley C: Aedes vexans (Meigen): an old foe. Proceedings of New Jersey Mosquito Control Association 2005, 1990:90-95.

22. Linthicum K, Davies F, Bailey C, Kairo A: Mosquito species succession dambo in an East African forest. Mosquito News 1983, 43:464-470.

23. Linthicum K, Davies F, Bailey C, Kairo A: Mosquito species encountered in a flooded grassland dambo in Kenya. Mosquito News 1984, 44:228-232.

24. Linthicum K, Anyamba A, Tucker C, Kelley P, Myers M, Peters C: Climate and satellite indicators to forecast Rift Valley fever epidemics in Kenya. Science 1999, 285:397-400.

25. Davies F, Linthicum K, James A: Rainfall and epizootic Rift Valley Fever. Bulletin of the World Health Organization 1985, 63:941-943.

26. Nicholls N: Teleconnections and health In Teleconnections Linking Worldwide Climate Anomalies. New York: Cambridge University PressGlantz MH, Katz RW, Nicholls N 1991, 493-510.

27. Sall A, Zanotto P, Vialat P, Sene O, Bouloy M: Origin of 1997-98 Rift Valley fever outbreak in East Africa. Lancet 1998, 352:1596-1597.

28. Sall A, Zanotto P, Sene O, Zeller H, Digoutte J, Thiongane Y, Bouloy M: Genetic reassortment of Rift Valley Fever virus in nature. J Virol 1999, 73:8196-8200.

29. Ahmad K: More deaths from Rift Valley fever in Saudi Arabia and Yemen. Lancet 2000, 356:1422.

30. Centers for Disease Control and Prevention, Wkly Epidemiol Rec: An outbreak of Rift Valley Fever, eastern Africa, 1997-1998. 1998, 73:105-109.

31. Soumare B, Tempia S, Cagnolati V, Mahmoud A, Huylenbroeck G, Berkvens D: Screening for Rift Valley fever infection in Northern Somalia: A GIS based survey method to overcome the lack of sampling frame. Vet Microbiol 2007, 121:249-256.

32. Woods C, Karpati A, Grein T, McCarthy N, Gaturuku P, Muchiri E: An Outbreak of Rift Valley fever in Northeastern Kenya, 1997-98. Emerg Infect Dis 2002, 8:138-144.

33. Shoemaker T, Boulianne C, Vincent M, Pezzanite L, Al-Qahtani M, AlMazrou Y: Genetic analysis of viruses associated with emergence of Rift Valley fever in Saudi Arabia and Yemen, 2000-01. Emerg Infect Dis 2002, 8:1415-1420.

34. Digoutte J, Peters C: General aspects of the 1987 Rift Valley fever epidemic in Mauritania. Res Virol 1989, 140:27-30.

35. Nabeth P, Kane Y, Abdalahi M, Diallo M, Ndiaye K, Ba K: Rift Valley fever outbreak in Mauritania in 1998: seroepidemiologic, virologic, entomologic, and zoologic investigation. Emerg Infect Dis 2001, 7:1052-1054.

36. World Health Organization: Report Update 4: Rift Valley Fever in Sudan. WHO Report, Update 4, December 21st 2007.

\section{Pre-publication history}

The pre-publication history for this paper can be accessed here:http://www. biomedcentral.com/1471-2334/10/65/prepub

doi:10.1186/1471-2334-10-65

Cite this article as: Seufi and Galal: Role of Culex and Anopheles mosquito species as potential vectors of rift valley fever virus in Sudan outbreak, 2007. BMC Infectious Diseases 2010 10:65.

\section{Submit your next manuscript to BioMed Central and take full advantage of:}

- Convenient online submission

- Thorough peer review

- No space constraints or color figure charges

- Immediate publication on acceptance

- Inclusion in PubMed, CAS, Scopus and Google Scholar

- Research which is freely available for redistribution

Submit your manuscript at www.biomedcentral.com/submit
C) Biomed Central 